\title{
Reimbursement of metformin for polycystic ovary syndrome
}

\author{
Metformina w zespole wielotorbielowatych jajników
}

\author{
Andrzej Milewicz \\ Department of Endocrinology, Diabetes and Radionuclide Therapy, Wroclaw Medical University, Wroclaw, Poland
}

\begin{abstract}
The latest list of reimbursed medicines includes, as a new addition, metformin for the treatment of polycystic ovary syndrome (PCOS), which is extremely important for practicing physicians. While this paper briefly summarises the current state of knowledge on PCOS, its main aim is to remind the reader about the effectiveness of metformin in women with PCOS in controlling glycaemia, increasing tissue sensitivity to insulin and affecting endothelial function, vascular inflammation, lipid profile and other risk factors of atherosclerosis, which suggests its cardioprotective effects. The paper also discusses the clinical effect of metformin relative to hyperandrogenism, menstrual cycle disorders and ovulation induction. The paper concludes with an algorithm for the diagnosis and management of PCOS. (Endokrynol Pol 2013; 64 (5): 409-414)
\end{abstract}

Key words: PCOS, metabolic abnormalities, metformin

\section{Streszczenie}

Ostatnia lista leków refundowanych uwzględnia po raz pierwszy metforminę w terapii choroby wielotorbielowatych jajników ( PCOS), co jest niezwykle istotne dla lekarzy praktyków. W artykule skrótowo podsumowano stan wiedzy na temat PCOS. Jednak głównym jego przesłaniem było przypomnienie efektywności terapii metforminą u kobiet z PCOS w kontroli glikemii, zwiększeniu wrażliwości tkanek na insulinę, wpływie na czynność śródbłonka, proces zapalny w naczyniach, profil lipidowy oraz inne czynniki ryzyka miażdżycy, co świadczy o jej działaniu kardioprotekcyjnym. Ponadto omówiono efekt kliniczny odnośnie hiperandrogenizmu, zaburzeń cyklu miesiączkowego oraz indukcji owulacji. Podsumowaniem artykułu jest zaprezentowanie schematu postępowania diagnostyczno-terapeutycznego PCOS. (Endokrynol Pol 2013; 64 (5): 409-414)

Słowa kluczowe: PCOS, zaburzenia metaboliczne, metformina

The latest list of reimbursed medicines has been a pleasant surprise: it now includes metformin when prescribed off-label to patients with prediabetes but also, importantly, when prescribed off-label to patients with PCOS. We finally have legal grounds for prescribing reimbursed metformin to women with PCOS, which was previously not possible, so we now have the green light.

I will now try to remind you why this is all so important and provide you with some new facts about the old, safe and inexpensive treatment with this medicine.

PCOS is one of the most common endocrinopathies in women of reproductive age. Its prevalence is estimated at about $6-10 \%$, or even $15 \%$ when the diagnosis is based on the Rotterdam criteria [1]. Three sets of diagnostic criteria for PCOS currently exist. The first, proposed by the National Institutes of Health $(\mathrm{NIH})$, combines menstruation disorders and chronic anovulation with hyperandrogenism [2]. According to the Rotterdam criteria, the diagnosis of PCOS may be made if any two out of the following three abnormalities are present: 1) chronic anovulation; 2) clinical and/ /or biochemical hyperandrogenism; and 3) polycystic ovaries on pelvic ultrasound [3]. According to the criteria most recently proposed by the Androgen Excess and PCOS Society, the diagnosis of PCOS requires both the presence of clinical and/or biochemical signs of hyperandrogenism and the presence of menstruation disorders with chronic anovulation or a characteristic sonographic morphology of the ovaries [4]. Each set of the diagnostic criteria of PCOS additionally requires exclusion of other causes of hyperandrogenism, such as: congenital adrenal hyperplasia, Cushing's syndrome, androgen-secreting tumours, hyperprolactinaemia, acromegaly, and thyroid diseases (Fig. 1).

Considerable controversy surrounds the definition of PCOS and the diagnosis of PCOS and of its main components. There is no single diagnostic criterion for this syndrome. There is no straightforward relationship between the severity of clinical and biochemical signs

Prof. Andrzej Milewicz M.D., Ph.D., Department of Endocrinology, Diabetes and Radionuclide Therapy, Wroclaw Medical University, Wroclaw ul. Pasteura 4, 50-367 Wrocław, Poland; e-mail: andrzej.milewicz@umed.wroc.pl 


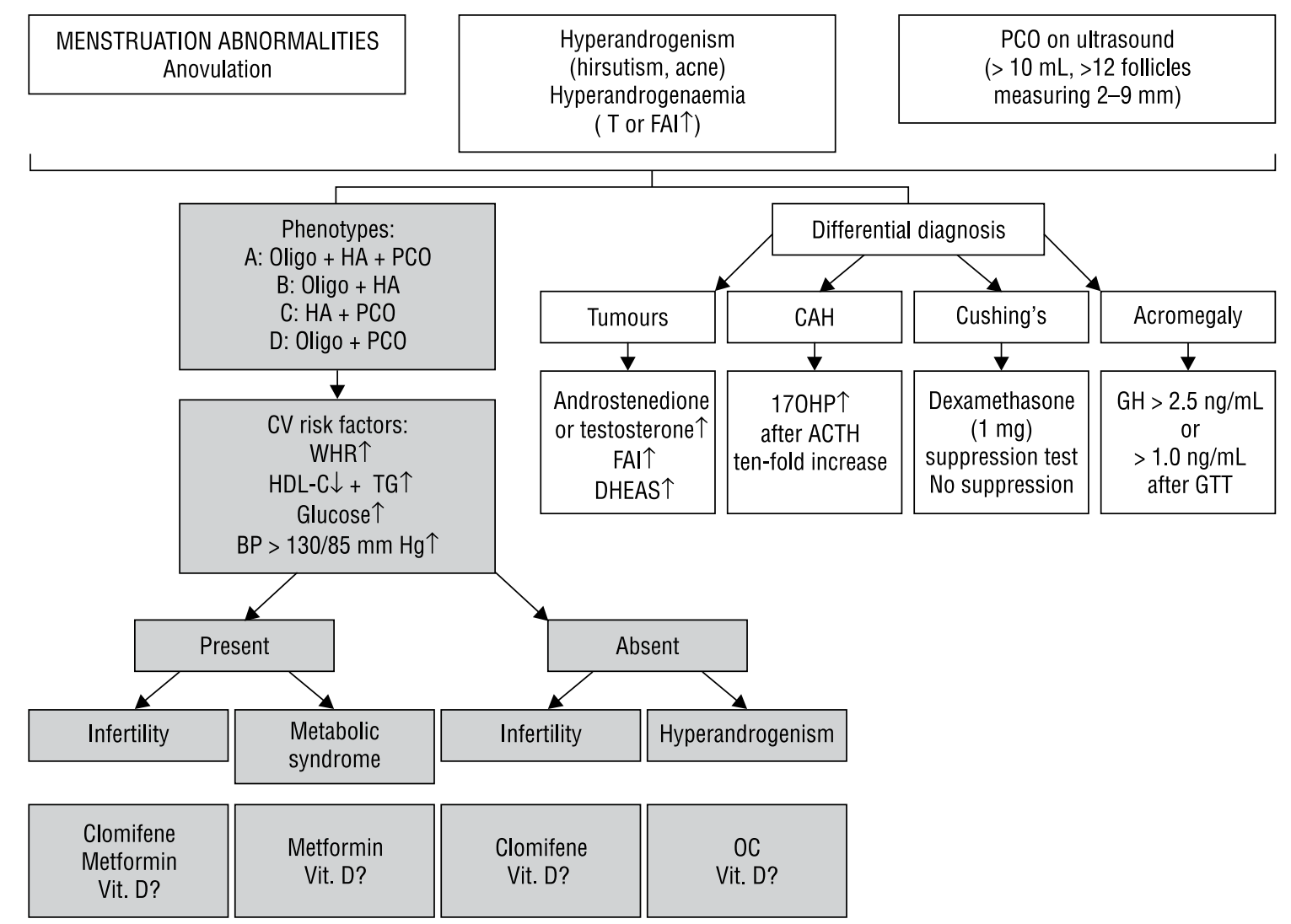

Figure 1. An algorithm for the diagnosis and management of PCOS

Rycina 1. Schemat postępowania diagnostyczno-terapeutycznego w PCOS

of hyperandrogenism. The clinical signs of hyperandrogenism, particularly hirsutism, are believed to be more useful in the diagnosis of PCOS than hyperandrogenaemia. On the other hand, hirsutism may be absent in women with elevated androgen levels, such as in Asian women, which is most likely due to ethnic factors. In addition, polycystic ovaries are found only in 50\% of hirsute women [5]. Measurement of free testosterone levels is recommended to demonstrate hyperandrogenaemia. Assessment of total testosterone levels may not be sufficient, as they are within the reference range in about $14 \%$ of women with PCOS [5]. If free testosterone cannot be determined, the free androgen index (FAI) may be used. The FAI is a ratio of total testosterone level in nmol/l to sex hormone binding globulin (SHBG) level in $\mathrm{nmol} / \mathrm{l}$ multiplied by $100 \%$.

The very definition of chronic anovulation is controversial. It is believed that fewer than 6-8 menstruations per year is an indicator of chronic anovulation. $43 \%$ of women with PCOS suffer from oligomenorrhoea (where the duration of menstrual cycles ranges from 35 to 199 days), $21 \%$ from secondary amenorrhoea (where the duration of menstrual cycles exceeds 199 days), and 7\% from primary amenorrhoea [1-6]. It should, however, be noted that up to $32 \%$ of women ovulate spon- taneously despite PCOS [6]. Sonographic diagnosis of polycystic ovaries requires the demonstration, in one or both ovaries, of 12 or more peripherally located follicles measuring 2 to $9 \mathrm{~mm}$ in diameter or an ovarian volume of more than $10 \mathrm{~cm}^{2}$. If a follicle measuring more than $10 \mathrm{~mm}$ in diameter is identified, the ultrasound scan needs to be repeated. It should be noted that about $30 \%$ of women with normal menstruation and with normal androgen levels may have polycystic ovaries, in which case the diagnosis of PCOS is not warranted.

The pathogenesis of PCOS has not been completely elucidated and is multifactorial, with genetic and environmental factors being implicated. Those genes thought to be involved in the pathogenesis of PCOS include genes associated with steroidogenesis, regulation of gonadotropin secretion, effects of insulin, obesity, factors regulating the body's energy expenditure, and genes associated with chronic inflammation [7]. A primary defect in the synthesis and metabolism of androgens in the ovaries resulting in an increased secretion of these hormones by the gonads is believed to be responsible for the development of PCOS. Neuroendocrine abnormalities leading to an increased secretion of luteinising hormone (LH) are also observed. 
Numerous studies have demonstrated a pathogenetic association of PCOS with insulin resistance and hyperinsulinaemia. Insulin resistance is thought to be caused by defects in the insulin receptor and post-receptor components of the insulin signalling pathway. According to Dunaif et al., in about $50 \%$ of patients with PCOS, insulin receptor autophosphorylation is impaired [8]. Phosphorylation of serine residues of this receptor interferes with its function and with downstream signalling. Phosphorylation of insulin receptor substrate 1 (IRS-1), stimulated by tumour necrosis factor alpha (TNF- $\alpha$ ) and leading to decreased activity of tyrosine kinase, may also play a role here [9]. Phosphorylation of serine residues may occur in cytochrome P450c17 and lead to increased activity of 17,20 -lyase and $17 \alpha$-hydroxylase. Free fatty acids and proinflammatory cytokines are believed to cause excessive phosphorylation of serine residues in the insulin receptor and cytochrome P450c17 resulting in insulin resistance and hyperandrogenism in PCOS [10]. Vitamin D deficiency and polymorphisms of vitamin D receptor genes (Cdx2, BsmI, FokI, ApaI and TaqI) have recently been implicated in the aetiology of the metabolic abnormalities in PCOS [11].

Insulin resistance in PCOS is mainly evident in the metabolic effects of insulin. Hyperinsulinaemia secondary to insulin resistance leads to an increased ovarian response to gonadotropins that is mainly manifested by overexpression of LH and IGF-1 receptors [12, 13]. Insulin increases the sensitivity of immature granulosa cells to LH, proliferation of thecal cells and the activity of enzymes required for androgen synthesis: $3 \beta$-hydroxysteroid dehydrogenase, $17 \alpha$-hydroxylase, and 17,20-lyase [14-18]. Another mechanism whereby insulin resistance causes hyperandrogenaemia involves reduced synthesis of SHBG, which results in increases in the bioavailability of testosterone to peripheral tissues [19]. Hyperinsulinaemia may also increase the activity of the hypothalamic-pituitary-adrenal axis and, as a result, the secretion of androgens by the adrenal glands [20].

According to various studies, up to $70 \%$ of women with PCOS are resistant to insulin, with about $50 \%$ of them being obese [10, 21]. Insulin resistance and obesity are also associated with a number of other metabolic abnormalities observed in PCOS. The prevalence of metabolic syndrome is 2-4 times higher compared to healthy controls [22, 23]. Abnormalities of carbohydrate metabolism observed in women with PCOS include an increased frequency of impaired glucose tolerance and of type 2 diabetes mellitus compared to controls matched for age and body mass index (BMI) [24]. Women with PCOS are also at a ten-fold higher risk of gestational diabetes than women in the general population [25]. Studies investigating metabolic abnormalities in PCOS have shown that the affected women have abnormalities of lipid metabolism manifested by decreased HDL-cholesterol levels and increased LDL-cholesterol and triglyceride levels [10]. Vascular wall abnormalities, such as an increased intima-media thickness [26] or the presence of calcium deposits in arterial walls, both indicative of an increased cardiovascular risk, have also been reported in patients with PCOS. The presence of endothelial dysfunction, an early marker of ischaemic heart disease in patients with PCOS, has been demonstrated in studies investigating abnormalities of vascular dilation relative to blood flow (flow-mediated dilation, FMD) [28, 29]. FMD has been shown to correlate positively with the insulin resistance index HOMA and negatively with the insulin sensitivity index QUICKI. There have also been reports of elevated levels of chronic inflammation markers, prothrombotic factors and factors associated with oxidative stress, such as: C-reactive protein, homocysteine, paraoxonase-1, fibrinogen, plasminogen activator inhibitor-1 (PAI-1), interleukin-6, TNF- $\alpha$, and nucleic factor kappa-B (NFкB) [30-37].

In conclusion, patients with PCOS have multiple cardiometabolic risk factors: obesity, insulin resistance, atherogenic lipid abnormalities, elevated levels of chronic inflammation markers and elevated levels of fibrinolysis markers. In order to prevent premature atherosclerosis, cardiovascular disease and type 2 diabetes mellitus in PCOS it is therefore necessary to treat these risk factors. Non-pharmacological interventions, namely lifestyle modifications and increased physical activity, should be at the forefront. However, these interventions may not always be effective if employed alone. A recent metaanalysis has shown that that while lifestyle modifications can reduce body mass, total testosterone levels, fasting insulin levels, hirsutism as assessed using the Ferriman-Gallwey score, and the waist-to-hip ratio (WHR), they do not affect BMI, SHBG levels, FAI, fasting glucose levels or lipid profile [24].

An important role in the management of many aspects of PCOS, particularly in the management of the metabolic abnormalities in the course of the disease, is therefore played by pharmacological treatment, particularly by treatment with drugs that increase insulin sensitivity, with metformin being the most important one.

Metformin belongs to the biguanide class of drugs. Although it has been available for more than 50 years, it continues to be widely used in clinical practice and its indications are expanding. The principal effect of metformin is to decrease insulin resistance. In addition, metformin exerts a pleiotropic protective effect on the cardiovascular system, which effect cannot be solely 
explained by improved glucose levels. Metformin decreases hepatic synthesis of glucose (gluconeogenesis), decreases absorption of glucose from the intestines and increases peripheral uptake and metabolism of glucose. An important effect of metformin at the cellular level is to increase the activity of the enzyme AMP kinase, which plays a crucial role in the regulation of carbohydrate and lipid metabolism [38]. AMP kinase affects, among other processes, the function of the glucose transporter GLUT4 and free fatty acid oxidation, which may result in decreased lipolysis in adipocytes [39].

Despite previously published reports of body mass reduction in patients treated with metformin, recent metaanalyses have not confirmed weight-reducing efficacy of metformin $[40,41]$. Metformin seems to have a neutral effect on body mass, although it may cause redistribution of fat from the active visceral adipose tissue to the metabolically inactive subcutaneous fat [42]. Metformin treatment beneficially affects lipid profile by decreasing total cholesterol, LDL-cholesterol and triglyceride both in patients with type 2 diabetes mellitus and in non-diabetic patients [41,43]. Numerous studies have shown beneficial antiatherosclerotic effects of metformin, such as improved endothelium-dependent vasodilation [44], decreased levels of endothelial activation markers, sVCAM-1 and E-selectin, decreased levels of PAI-1 [45], decreased levels of CRP [46], suppressed monocyte adhesion to cultured vascular wall cells and suppressed monocyte conversion to foam cells [47]. Metformin may also exert an antioxidant effect by decreasing the formation of advanced glycation endproducts (AGE) [48].

There is also evidence of beneficial effects of metformin in non-alcoholic fatty liver. An improvement in liver function tests (decrease in liver aminotransferase levels), a decrease in liver fat and an increase in insulin sensitivity have been shown in patients with non-alcoholic fatty liver treated with metformin [49]. Another potential action of insulin is its antitumour effect. Observational studies have shown a reduction of cancer-related mortality in patients with type 2 diabetes mellitus treated with metformin [50].

Metformin is used in the treatment of many components of PCOS, with type 2 diabetes mellitus, impaired glucose tolerance and insulin resistance being the principal indications. Numerous publications have also reported positive effects of metformin on other cardiometabolic risk factors present in PCOS. These effects include improved endothelial function [51, 52], improved levels of inflammation markers [52,53] and improved coronary reserve [54]. A metaanalysis has shown a decrease in LDL-cholesterol levels in patients with PCOS treated with metformin [41] and an observational study has revealed a dose-dependent $(1,500$ $\mathrm{mg}$ vs 2,550 $\mathrm{mg}$ ) body mass reduction in women with this condition [55].

Although a reduction in androgen levels by metformin has been reported in several studies $[56,57]$, this biguanide is not very effective in reducing the severity of hirsutism in PCOS. Most studies have shown no evidence of hirsutism-reducing activity of metformin [58, 59], which is why this drug is not used in the management of hyperandrogenism. The principal role in the treatment of menstruation disorders is played by oral contraceptives. The possible contraindications to oral contraceptives in women with PCOS should, however, be borne in mind. These agents may further exacerbate insulin resistance and increase cardiovascular and thrombotic risk, which is why it is beneficial to combine them with metformin. However, according to recent studies, oral contraceptives do not increase metabolic risk in women with PCOS [57].

The reported percentage of women in whom metformin regulates their menstrual cycle varies between $23 \%$ and $90 \%$, while the results of studies investigating the impact of this drug on ovulation and pregnancy rates remain inconclusive. According to some studies, metformin increases ovulation and pregnancy rates from $5 \%$ to $18 \%$, while according to other studies, similar effects may be obtained by lifestyle modifications and weight reduction [60]. A Cochrane review has shown that metformin treatment may result in a four-fold increase in the ovulation rate and a threefold increase in the pregnancy rate versus placebo or no treatment, although these results did not reach statistical significance [58]. According to the most recent consensus statements, the addition of metformin to clomifene in the treatment of infertility in women with PCOS results in no evident benefit [61]. An important issue in PCOS is the increased risk of miscarriage of up to $30-50 \%$ in women with this condition. During pregnancy, the levels of glycodelin and IGFBP-1 fall, and these abnormalities are worsened by hyperinsulinaemia. By stimulating glycodelin secretion, metformin may reduce the incidence of early miscarriage in women with PCOS $[62,63]$.

Metformin treatment in patients with PCOS not only improves glycaemic control and tissue sensitivity to insulin but also - as a result of its effects on endothelial function, vascular inflammation, lipid profile and other risk factors of atherosclerosis - exerts cardioprotective effects and may reduce cardiovascular risk. Patients with PCOS are a heterogenous group in terms of phenotypes distinguished on the basis of specific clinical presentations necessary for the diagnosis. This classification distinguishes the 'classic' phenotype in which all the three criteria required for diagnosis are present (oligomenorrhoea, hyperandrogenism and polycystic 
ovaries [phenotype A]) and three other phenotypes which are combinations of two of the criteria required for diagnosis (oligomenorrhoea and hyperandrogenism [phenotype B]; hyperandrogenism and polycystic ovaries [phenotype C]; oligomenorrhoea and polycystic ovaries [phenotype D]. Taking this classification into consideration, the most common metabolic abnormalities were observed in the 'classic' phenotype [21].

Figure 1 illustrates an algorithm for the diagnosis and management of PCOS which takes into account the recommendations of the ESHRE/ASRM (Amsterdam, 2012). In the diagram, the starting point for therapeutic interventions is the presence of cardiovascular risk factors, i.e. obesity, abnormalities of carbohydrate metabolism, abnormalities of lipid metabolism, and hypertension.

Please do not forget to measure vitamin D levels in patients with PCOS. I hope you find the diagram useful in your everyday practice.

\section{References}

1. Consensus on women's health aspects of polycystic ovary syndrome (PCOS): the Amsterdam ESHRE/ASRM - Sponsored 3rd PCOS Consensus Workshop Group. Fertil Steril 2012; 97: 28-38.e25.

2. Zawadzki JK, Dunaif A. Diagnostic criteria for polycystic ovary syndrome: towards a rational approach. In: Dunaif A, Givens JR, Haseltine FP, Merriam GR. Polycystic ovary syndrome. Boston: Blackwell Scientific 1992; 377-384.

3. Rotterdam ESHRE/ASRM-Sponsored PCOS Consensus Workshop Group. Revised 2003 consensus on diagnostic criteria and long-term health risks related to polycystic ovary syndrome. Fertil Steril 2004; 81: 19-25.

4. Azziz R. Diagnostic criteria for polycystic ovary syndrome: a reappraisal Fertil Steril 2005; 83: 1343-1346.

5. Legro R. American Endocrine Society, Curr Opin Endocrinol Diabetes Obes 2008; 15: 30-36.

6. Takara S. Current Opinion in Endocrinol Diabetes and Obesity 2008 15: 30-36.

7. Escobar-Morreale HF, Luque-Ramirez M, San Millan JL. The moleculargenetic basis of functional hyperandrogenism and the polycystic ovary syndrome. Endocr Rev 2005; 26: 251-282.

8. Dunaif A, Xia J, Book CB, Schenker E et al. Excessive insulin receptor serine phosphorylation in cultured fibroblasts and in skeletal muscle. A potential mechanism for insulin resistance in the polycystic ovary syndrome. J Clin Invest 1995; 96: 801-810.

9. Dunaif A. Insulin action in the polycystic ovary syndrome. Endocrinol Metab Clin North Am 1999; 28: 341-359.

10. Dunaif A. Insulin Resistance and the Polycystic Ovary Syndrome: Mechanism and Implications for Pathogenesis. Endocr Rev 1997; 18: 774-800.

11. Lerchbaum E, Obermayer-Pietsch B. Vitamin D and fertility - a systematic review. Eur J Endocrinol 2012, 166, 765-778.

12. Book CB, Dunaif A. Selective insulin resistance in the polycystic ovary syndrome. J Clin Endocrinol Metab 1999; 84: 3110-3116.

13. Poretsky L, Cataldo NA, Rosenwaks Z et al. The insulin - related ovarian regulatory system in health and disease. Endocr Rev 1999; 20: 535-582

14. Zhang G, Garmey JC, Veldhuis JD. Interactive stimulation by luteinizing hormone and insulin of the steroidogenic acute regulatory (StAR) protein and 17alpha-hydroxylase/17,20-lyase (CYP17) genes in porcine theca cells. Endocrinology 2000; 141: 2735-2742.

15. Duleba AJ, Spaczynski RZ, Olive DL. Insulin and insulin-like growth factor I stimulate the proliferation of human ovarian theca - interstitia cells. Fertil Steril 1998; 69: 335-340.

16. McGee E, Sawetawan C, Bird I et al. The effects of insulin on 3 beta hydroksysteroid dehydrogenase expression in human luteinized granulose cells. J Soc Gynecol Investing 1995; 2: 535-541.

17. Miller WL. Molecular biology of steroid hormone synthesis. Enocrino Rev 1988; 9: 295-318.

18. Nestler JE, Jakubowicz DJ. Decreases in ovarian cytochrome P450c17 alpha activity and serum free testosterone after reduction of insulin secretion in polycystic ovary syndrome. N Engl J Med 1996; 335: 617-623.

19. Nestler JE, MattDW, Steingold Ket al. A direct effect of hyperinsulinemia on serum sex hormone-binding globulin levels in obese women with the polycystic ovary syndrome. J Clin Endocrinol Metab 1991; 72: 83-89.
20. Moghetti P, Castello R, Negri C et al. Insulin infusion amplifies 17- $\alpha$ hydroxycorticosteroid intermediates response to $\mathrm{ACTH}$ in hyperandrogenic women: apparent relative impairment of 17, 20-lyase activity. J Clin Endocrinol Metab 1996; 81: 881-886.

21. Franks S. Polycystic ovary syndrome. N Engl J Med 1995; 333: 863-861.

22. Yildiz BO, Bozdag G, Yapici Z et al. Prevalence, phenotype and cardiometabolic risk of polycystic ovary syndrome under different diagnostic criteria. Hum Reprod 2012; 27: 3067-3073.

23. Moran C, Tena G, Moran S et al. Prevalence of polycystic ovary syndrome and related disorders in Mexican women. Gynecol Obstet Invest 2010; 69: 274-280.

24. Moran LJ, Hutchison SK, Norman RJ et al. Lifestyle changes in women with polycystic ovary syndrome. Cochrane Database Syst Rev 2011 CD007506.

25. Glueck CJ, Wang P, Kobayashi S et al. Metformin therapy throughout pregnancy reduces the development of gestational diabetes in women with polycystic ovary syndrome. Fertil Steril 2002; 77: 520-525.

26. Luque-Ramirez M, Mendieta-Azcona C, Alvarez-Blasco F et al. Androgen excess is associated with the increased carotid intima-media thickness observed in young women with polycystic ovary syndrome. Hum Reprod 2007; 22: 3197-3203.

27. Talbott EO, Zborowski JV, Rager JR et al. Evidence for an association between metabolic cardiovascular syndrome and coronary and aortic calcification among women with polycystic ovary syndrome. J Clin Endocrinol Metab 2004; 89: 5454-5461.

28. Carmina E, Orio F, Palomba S et al. Endothelial dysfunction in PCOS: role of obesity and adipose hormones. Am J Med 2006; 119: 356 e 1-6.

29. Foltyn W, Strzelczyk J, Marek B et al. Selected markers of endothelial dysfunction in women with polycystic ovary syndrome. Endokrynol Pol 2011; 62: 243-248.

30. Kelly CCJ, Lyall H, Petrie JR et al. Low Grade Chronic Inflammation in Women with Polycystic Ovarian Syndrome. J Clin Endocrinol Metab 2001; 86: 2453-2455.

31. Guzelmeric K, Alkan N, Pirimoglu M et al. Chronic inflammation and elevated homocysteine levels are associated with increased body mass index in women with polycystic ovary syndrome. Gynecol Endocrinol 2007; 23: 505-510.

32. Fenkci IV, Serteser M, Fenkci S et al. Paraoxonase levels in women with polycystic ovary syndrome. J Reprod Med 2007; 52: 879-883.

33. Atiomo WU, Fox R, Condon JE et al. Raised plasminogen activator inhibitor-1 (PAI-1) is not an independent risk factor in the polycystic ovary syndrome (PCOS). Clin Endocrinol (Oxf) 2000; 52: 487-492.

34. Glueck CJ, Wang P, Fontaine RN et al. Plasminogen activator inhibitor activity: an independent risk factor for the high miscarriage rate during pregnancy in women with polycystic ovary syndrome. Metabolism 1999; 48: 1589-1595.

35. Benson S, Janssen OE, Hahn S et al. Obesity, depression, and chronic low-grade inflammation in women with polycystic ovary syndrome. Brain Behav Immun 2008; 22: 177-184.

36. Sayin NC, Gucer F, Balkanli-Kaplan P et al. Elevated serum TNF-alpha in normal-weight women with polycystic ovaries or the polycystic ovary syndrome. J Reprod Med 2003; 48: 165-170.

37. Gonzalez F, Rote NS, Minium J et al. Increased activation of nuclear factor kappaB triggers inflammation and insulin resistance in polycystic ovary syndrome. J Clin Endocrinol Metab 2006; 91: 1508-1512.

38. Mahmood K, Naeem M, Rahimnajjad NA. Metrofmin: The hidden chronicles of a magic drug. European Journal of Internal Medicine 2013; 24: 20-26.

39. Gregorio F, Ambrosi F, Manfrini S et al. Metformin, plasma glucose and free fatty acids in type II diabetic out-patients: results of a clinical study. Diabet Res Clin Pract 1997; 37: 21-33.

40. Saenz A, Fernandez-Esteban I, Mataix A et al. Metformin monotherapy for type 2 diabetes mellitus. Cochrane Database Syst Rev 2005; CD002966.

41. Lord JM, Flight LH, Norman RJ. Metformin in polycystic ovary syndrome: systematic review and metaanalysis. BMJ 2003; 327: 951-953.

42. Kurukulasuriya $\mathrm{R}$, Banerji MA, Chaiken $\mathrm{R}$ et al. Selective decrease in visceral fat is associated with weight loss during metformin treatment in African Americans with type 2 diabetes. Diabetes 1999; 48 (Suppl.): A315.

43. DeFronzo RA, Goodman AM. Efficacy of metformin in patients with non-insulin-dependent diabetes mellitus. The multicenter metformin study group. N Engl J Med 1995; 333: 541-549.

44. KJ, Verma S, Anderson TJ. Improved endothelial function with metformin in type 2 diabetes mellitus. J Am Coll Cardiol 2001; 37: 1344-1350.

45. De Jager J, Kooy A, Lehert P et al. Effects of short-term treatment with metformin on markers of endothelial function and inflammatory activity in type 2 diabetes mellitus: a randomized, placebo-controlled trial. J Int Med 2005; 257: 100-109.

46. Haffner $\mathrm{S}$, Temprosa M, Crandal J et al. Intensive lifestyle intervention or metformin on inflammation and coagulation in participants with impaired glucose tolerance. Diabetes 2005; 54: 1566-1572. 
47. Mamputu JC, Wiernsperger N, Renier G. Metformin inhibits monocyte adhesion to endothelial cells and foam cell formation. Br J Diabet Vasc Dis 2003; 3: 302-310.

48. Beisswenger P, Ruggiero-Lopez D. Metformin inhibition of glycation processes. Dabet Metab 2003; 29: 6595-65103.

49. Schwimmer JB, Middleton MS, Deutsch R et al. A phase 2 clinical trial of metformin as a treatment for non-diabetic paediatric non-alcoholic steatohepatitis. Alimentary Pharmacology and Therapeutics 2005; 21: 871-879.

50. Evans JM, Donnelly LA, Emslie-Smith AM et al. Metformin and reduced risk of cancer in diabetic patients. BMJ 2005; 330: 1304-1305.

51. Orio F Jr, Palomba S, Cascella $\mathrm{T}$ et al. Improvement in endothelial structure andfunction after metformin treatment in young normal-weight women with polycystic ovary syndrome: results of a 6-month study. J Clin Endocrinol Metab 2005; 90: 6072-6076.

52. Diamanti-Kandarakis E, Alexandraki K, Protogerou A et al. Metformin administration improves endothelial function in women with polycystic ovary syndrome. Eur J Endocrinol 2005; 152: 749-756.

53. Morin-Papunen L, Rautio K, Ruokonen A et al. Metformin reduces serum C-reactive protein levels in women with polycystic ovary syndrome. J Clin Endocrinol Metab 2003; 88: 4649-4654.

54. Topcu S, Tok D, Caliscan M et al. Metformin therapy improves coronary microvascular function in patients with polycystic ovary syndrome and insulin resistance. Clin Endocrinol 2006; 65: 75-80.

55. Harborne LR, Sattar N, Norman JE et al. Metformin and weight loss in obese women with polycystic ovary syndrome: comparison of doses. J Clin Endocrinol Metab 2005; 90: 4593-4598.
56. Lord JM, Flight LH, Norman RJ. Insulin-sensitising drugs (metformin, troglitazone, rosiglitazone, pioglitazone, D-chiro-inositol) for polycystic ovary syndrome. Cochrane Database of Systematic Reviews 2003; 3: CD003053.

57. Costello MF. Shrestha B, Eden J et al. Metformin versus oral contraceptive pill in polycystic ovary syndrome: a Cochrane review. Hum Reprod 2007; 22: 1200-1209.

58. Harborne L, Fleming R, Lyall $\mathrm{H}$ et al. Metformin or antiandrogen in the treatment of hirsutism in polycystic ovary syndrome. J Clin Endocrinol Metab 2003; 88: 4116-23.

59. Cosma M, Swiglo BA, Flynn DN et al. Clinical review: insulin sensitizers for the treatment of hirsutism: a systematic review and metaanalyses of randomized controlled trials. J Clin Endocrinol Metab 2008; 93: 1135-1142.

60. Glueck CJ, Wang P, Fontaine R et al. Metformin-induced resumption of normal menses in 39 of $43(91 \%)$ previously amenorrheic women with the polycystic ovary syndrome. Metabolism 1999; 48: 511-519.

61. Consensus on infertility treatment related to polycystic ovary syndrome. The Thessaloniki ESHRE/ASRM-Sponsored PCOS Consensus Workshop Group, March 2-3, 2007. Fertil Steril 2008; 89: 505-522.

62. Nestler JE, Azziz R. Dyskusja ekspertów American Endocrine Society, San Francisco, 2008.

63. Khattab S, Mohsen LA, Foutouh LA et al. Metformin reduces abortion in pregnant women with polycystic ovary syndrome. Gynecol Endocrinol 2006; 22: 680-684. 